\title{
Characterization of the Deposition of Collagen Fibers and Lithogenic Potential in Bladder of Rats Submitted to a Sugar Cane Biopolymer Graft
}

\author{
Arlindo Monteiro de Carvalho Junior, Marina Moura Santos, Beda Barros Barkokébas, José Lamartine de
} Andrade Aguiar, Salvador Vilar Correia Lima, Miriam Dambros

Federal University of Pernambuco (UFPE), Recife, PE and Federal University of São Paulo (UNIFESP), São Paulo, SP, Brazil

\section{ABSTRACT}

Objectives: Suture materials are widely used in urology. The interaction of these materials with the extracellular matrix in the inflammatory process can be estimated by stereology of collagen fibers and the present study was designed to determine the behavior of the bladder tissue of rats to grafts of the biopolymer of sugar cane (BPCA), and the inflammation and intravesical stone formation compared to the polyglactin 910.

Materials and Methods: 42 Wistar rats were divided in four groups: Group I ( $\mathrm{n}=10)$ rats submitted to bladder implantation of 4-0 BPCA suture graft and euthanized at 4 weeks; Group II $(\mathrm{n}=10)$ rats submitted to bladder implantation of 4-0 polyglactin 910 suture graft and euthanized at 4 weeks; Group III $(n=12)$ rats submitted to bladder implantation of 4-0 BPCA suture graft and euthanized at 8 weeks; Group IV $(\mathrm{n}=10)$ rats submitted to bladder implantation of 4-0 polyglactin 910 suture graft and euthanized at 8 weeks. Bladders collected at necropsy were analyzed for their weight and the presence of grafts and calculi. Sections were prepared for stereological analysis of collagen fibers.

Results: The bladder weight was higher in group I, particularly in the presence of bladder stones. The presence of the graft was observed in 100\% (group I), 80\% (group II), 91.6\% (group III) and 30\% (group IV); polyglactin 910 showed an absorption of 70\% in this period. The stereological analysis showed a higher volume density of collagen fibers in group I versus other groups ( $\mathrm{p}<0.001)$.

Conclusion: The BPCA was a material with good integration into the bladder of rats; its absorption was slower than that of the polyglactin 910. The presence of urinary stones was lower in bladders with implantation of BPCA, particularly after 8 weeks. There was a greater initial inflammatory response to BPCA graft that was directly related to the increase in bladder weight and the presence of urinary stones, but that equalized the results of polyglactin 910 after 8 weeks.

\section{ARTICLE INFO}

\section{Key words:}

Biopolymers; Collagen;

Inflammation; Sutures

Int Braz J Urol. 2012; 38: 544-51

Submitted for publication:

May 26, 2011

Accepted after revision:

July 23, 2012

\section{INTRODUCTION}

Suture materials are widely used in urological surgeries, mainly in tissues with contact to urine. Experimental and clinical studies research the best material with less immunological reac- tion, low cost and low inflammatory reaction, to reduce the risk of urinary stones and fistulae. In the urinary tract, several materials present a good response: polyglactin 910, polydioxanone, simple and chrome catgut, polyglicolic acid, all of them absorbable in variable times (1-3). As an advance 
of biomaterials it was developed a very compatible and pure polymer obtained from sugar cane, through a reducer process treatment of residual sugars, made only of polymered sugars and glicuronic acid: the sugar cane biopolymer (BPCA). BPCA presents elasticity, resistance to traction and flexibility that are suitable for biological grafts (4), and it has been widely used in several tissues and in many forms in animal experiments: arterial prosthesis, reconstruction of timpanic membrane, ureteral reconstruction, slings and cell conductor in cell cultures (4-8). In veterinary medicine, it has a very important role in biological dressings for cutaneous wounds, showing a bacteriostatic and bactericidal effect that favor healing (5). Our goal was to evaluate the integration of sugar cane biopolymer graft in rat bladders, comparing the results with those of polyglactin 910, studying the presence of bladder stones related to the behavior of the material and weight of the bladders, determining the tissue inflammatory response and bladder fibrosis of host and control rats after BPCA graft.

\section{MATERIALS AND METHODS}

Forty two adult healthy Wistar rats were used, weighting 250-350g, maintained in controlled environment $(25 \pm 20 \mathrm{C})$, exposed to daily light for 12 hours with water ad libitum and Labina ${ }^{\circledR}$ (Purina ${ }^{\circledR}$ ) chow, randomly and sequentially distributed in 4 groups (without interference of researchers):

Group I: Ten animals. Cystotomy of anterior bladder wall $(1.0 \mathrm{~cm}$ wide) and bladder closure with continuous suture of BPCA. Euthanized after 4 weeks and submitted to cystectomy.

Group II: Ten animals. Cystotomy of anterior bladder wall $(1.0 \mathrm{~cm}$ wide) and bladder closure with continuous suture of Polyglactin 4-0. Euthanized after 4 weeks and submitted to cystectomy.

Group III: Twelve animals. Cystotomy of anterior bladder wall (1.0 cm wide) and bladder closure with continuous suture of BPCA. Euthanized after 8 weeks and submitted to cystectomy.

Group IV: Ten animals. Cystotomy of anterior bladder wall $(1.0 \mathrm{~cm}$ wide) and bladder closure with continuous suture of Polyglactin 4-0.
Euthanized after 8 weeks and submitted to cystectomy.

\section{Studied material (BPCA)}

During the process of production of BPCA, the bacteria Zoogloea sp. is used in GLP medium, that contains the following reagents per liter: glucose (20.0g), yeast extract (5.0g), peptone (3.0g) and agar (15.0g). Raw material consisted of sugar cane molasses adjusted to a 15\% brix, $\mathrm{pH}=5$. The culture is inoculated in erlenmeyers at $300 \mathrm{C}$ for up to 7 days. The produced material is dried in incubator with air circulation and sterilized in autoclave at $120 \mathrm{o} \mathrm{C}$ during 30 minutes and the obtained material is used in several forms and shapes according to the proposed study or experiment. The biomembrane has a very well defined temperature of crystalline fusion $(1180 \mathrm{C})$, low cytotoxicity and high biocompatibility when in vitro evaluated in relation to two other biomaterials: polypropylene and polytetrafluoroetylen (PTFE), that allowed its experimental use with safety $(9,4)$. BPCA grafts were obtained from a single lot and prepared as a suture line of approximately a 4-0 diameter, sealed in isopropilic alcohol and sterilized with gamma radiation (y).

The chosen control was polyglactin 910, a multifilamentar copolymer of biological source made of 90\% glycolide and 10\% L-lactide, nonantigenic, non-pyrogenic, widely described in the literature in order to compare the histological response in the bladder wall with the results of that new material $(1,2)$. It is indicated for the use in all but cardiovascular and neurological tissues, and is absorbable with minimal inflammatory reaction (10).

\section{Surgical Technique}

The animal was anesthetized and maintained in horizontal dorsal position, fixed to the surgical table with elastic bands with the members extended. The abdominal wall was cleaned with a solution of PVPI 10\% - active iodine and dressed with surgical sheets. A $3 \mathrm{~cm}$ infraumbilical incision of the medium line was made, opening the aponeurosis and the peritoneum. A $1.0 \mathrm{~cm}$ opening of the anterior wall was obtained up to 
the bladder dome with scissors. The BPCA grafted wires or sutures of polyglactin 910 (Vicryl ${ }^{\circledR}$ ) were applied in a continuous suture encompassing all the bladder wall, with minimal tension and with the knot facing the bladder interior. The closure of the abdominal aponeurosis was made with polyglactin 910 continuous suture. The procedure was made under 2.5 magnification using magnifying glass.

After euthanized, the animals were submitted to the resection of the bladder (that was cut close to the bladder neck). The exterior was observed (presence of the graft) and afterwards it was open in order to look for bladder stones. If present, they were removed. Then, a suture of nylon 4-0 was applied at the bladder dome in order to hold the bladder while it was immersed in a becker filled with saline (0.9\%), in order to exclude the atmospheric pressure for the final measure of the bladder weight (11). Since the specific gravity of the saline (0.9) is 1.0048 , the final weight of the bladder is equal to the fixed constant $\mathrm{x}$ final weight in grams, that was measured by a Morien MR $6000 / 0^{\circledR}$ precise scale digital balance.

\section{Fixation of the harvest material and preparation of slides}

The bladders were completely open and fixed with pins at their angles, immersed during 48 hours in buffered formalin 10\% (12). The region of the bladder dome was stained with nankeen. After these procedures, we obtained longitudinal strips including all tissues, in order to include the bladder wall in paraffin blocks. These were cut $7 \mu$ wide and the different cuts were stained with Picro-sirius Red in order to identify the collagen fibers and to perform the stereological analysis (13). All samples were evaluated by the same pathologist.

\section{Stereological analysis}

The inflammatory reaction was analyzed through quantification of collagen fibers by stereology, based on the principle described by Delesse (14). We used the superposition of the test-system M-42 over the morphological computerized image of the slide observed under an optical microscope Olympus BX 51"® - 10X and 40X, with an Olympus camera DP $71^{\circledR}$ attached. The used software was Pro-Plus 6.1. (DP Controller) and the fibers were quantified under a magnification of 400X, in 10 random microscopical fields, for every sample. We used the formula $\mathrm{v}=(\mathrm{Pp} / \mathrm{Pt}) \times 100 \%$ to calculate the volumetric density (Vv) of the collagen fibers, where $\mathrm{Pp}=$ number of points on the structure (collagen fibers) and $\mathrm{Pt}=$ number of posts tested (in this case, 42).

\section{Statistical Analysis}

We used the statistical software GraphPad Prism 5 for Windows, using variance analysis for non-parametrical samples, and when $\mathrm{p}<0.05$, the Tukey post-test was used to identify the differences among the groups. $\mathrm{P}<0.05$ was established as criteria for statistical significance. For the analysis of the relation between bladder weight versus presence or absence of graft, and the relation of the presence of the graft versus presence of bladder stones, it was used the Qui-square test.

\section{RESULTS}

At the time of the cystotomy + bladder closure, the median body weight was 352.6 g (324-399 g) in group I and 336.4 (293-396g) in group II. Group III presented a median weight of $327.75 \mathrm{~g}$ (290-374g) and group IV 325.8g (263$388 \mathrm{~g})$. There was no statistical difference among the groups. At the time of euthanasia and cystectomy, the median body weight of group I was 372g (336-421g), 339g (245-408g) group II. Group III showed median weight of 395.83g (351-444g) and group IV 396.5 (348-458g), and there was no statistical difference among the groups in the same interval of time $(\mathrm{p}<0.05)$.

Table- 1 presents the relation between the bladder weight and the presence of material at the moment of euthanasia and harvest of the bladders. It was observed a difference between groups I and III and I and IV (non comparable) in relation to the presence of material. There were no differences among the other groups $(p<0.05)$, especially when the comparison was made among the groups submitted to surgery in the same time interval.

At the time of euthanasia, the presence of graft was observed in 100\% (group I), 80\% (group 
Table 1 - Comparison of bladder weight and the presence of the material at the moment of euthanasia in the 4 studied groups.

\begin{tabular}{lccccc}
\hline & & \multicolumn{4}{c}{ MEDIUM WEIGHT OF BLADDER (g) } \\
\cline { 3 - 6 } & & GROUP I & GROUP II & GROUP III & GROUP IV \\
\hline Presence of material & YES & 0.38 & 0.28 & 0.2 & 0.2 \\
NO & 0 & 0.2 & 0.2 & 0.27 \\
Median of group & & 0.38 & 0.28 & 0.2 & 0.25 \\
\hline
\end{tabular}

$\mathrm{p}<0.05$ between groups I and II, and between groups I and IV (non comparable).

p $>0.05$ between groups I and II and between groups III and IV.

II), 91.6\% (group III) and 30\% (group IV) of animals. The absorption of the BPCA graft was only 8.4\% after 8 weeks while for polyglaction 910 the absorption was of 70\% after the same period of time (Table-2). At the same table, it is possible to observe that, despite the differences of absorptions, there is a $60 \%$ presence of stones in group I, 70\% in group II, 8.3\% in group III and 50\% in group IV. In groups II and IV, there was a $20 \%$ and 40\% presence of stones respectively, in the absence of material. Group III showed the lower rate of stones in spite of the low absorption of the material, in the maximal period of the study.

Analysis of Volumetric Density of Collagen Fibers

There was a difference between the median volumetric density $(\mathrm{Vv})$ of group I in relation to the other groups. There was no difference between median Vv of groups II and IV. The same was observed between groups III and IV. Figure-1 demonstrates this fact, showing the higher median volumetric density ( $\mathrm{Vv}$ ) of fibers in the bladders of rats of group I (BPCA graft after 4 weeks). Figures 2A and $\mathrm{B}$ illustrate the density of the collagen fibers in the bladder wall of animals from groups I and II, euthanized after 4 weeks. Figures $3 \mathrm{~A}$ and B show the presence of graft in samples obtained from animals of groups I and III, respectively. There is a higher density of these fibers, corresponding to the denser red color of the connective tissue of bladders of the animals of group I (BPCA).

\section{DISCUSSION}

The physical proprieties of a polymer depend on its length and molecular mass; due to

Table 2 - Comparison of the presence of the material and the presence of stones at the moment of euthanasia in the 4 studied groups.

\begin{tabular}{|c|c|c|c|c|c|c|c|c|c|}
\hline & & \multicolumn{8}{|c|}{ PRESENCE OF STONES } \\
\hline & & \multicolumn{2}{|c|}{ GROUP I } & \multicolumn{2}{|c|}{ GROUP II } & \multicolumn{2}{|c|}{ GROUP III } & \multicolumn{2}{|c|}{ GROUP IV } \\
\hline & & YES & NO & YES & NO & YES & NO & YES & NO \\
\hline \multirow[t]{2}{*}{$\begin{array}{l}\text { Presence of } \\
\text { the material }\end{array}$} & YES & $\begin{array}{c}6 \\
(60 \%)\end{array}$ & $\begin{array}{c}4 \\
(40 \%)\end{array}$ & $\begin{array}{c}5 \\
(50 \%)\end{array}$ & $\begin{array}{c}3 \\
(30 \%)\end{array}$ & $\begin{array}{c}1 \\
(8.3 \%)\end{array}$ & $\begin{array}{c}10 \\
(83.3 \%)\end{array}$ & $\begin{array}{c}1 \\
(10 \%)\end{array}$ & $\begin{array}{c}2 \\
(20 \%)\end{array}$ \\
\hline & NO & $\begin{array}{c}0 \\
(0 \%)\end{array}$ & $\begin{array}{c}0 \\
(0 \%)\end{array}$ & $\begin{array}{c}2 \\
(20 \%)\end{array}$ & $\begin{array}{c}0 \\
(0 \%)\end{array}$ & $\begin{array}{c}0 \\
(0 \%)\end{array}$ & $\begin{array}{c}1 \\
(8.3 \%)\end{array}$ & $\begin{array}{c}4 \\
(40 \%)\end{array}$ & $\begin{array}{c}3 \\
(30 \%)\end{array}$ \\
\hline
\end{tabular}

$\mathrm{p}<0.05$ between groups $\mathrm{I} / \mathrm{II}$ and $\mathrm{II} / \mathrm{IV}$ in the presence of stones.

$p>0.05$ between groups I/III and IV, considerin the absorption of the material. 
Figure 1 - Volumetric density (\%) of collagen fibers in the rat bladders according to the studied group.

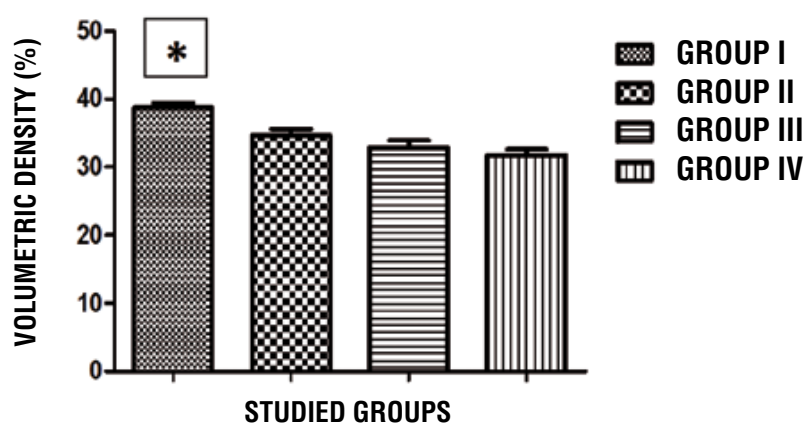

${ }^{*} p<0.05$ between groups I and others.

${ }^{*} \mathrm{p}>0.05$ between groups II and IV and between groups III and IV. this fact, they suffer a great variation, as observed with plastics, rubbers and fibers, macromolecules obtained through a process called polymerization. The polysaccharides produced through microbiological synthesis and excreted in soluble and insoluble forms $(15,16)$ are biopolymers, that include the sugar cane one (BPCA) used in our experiment. The choice of the rat for animal experiments occurred due to the facility to purchase, the possibility to use an adequate quantity of animals, the great resistance to infections, low cost, genetic homogeneity and similarity of exposition to injuries.

Being a foreign body, the sustained contact of sutures with saline solutions, as contained in urinary and biliary tracts, can lead to

Figures 2A and 2B - Samples of groups I and II, respectively. The red color is more intense in group I. Observe the collagen fibers (arrows). Stained with Picro Sirius Red -100X magnification.

A

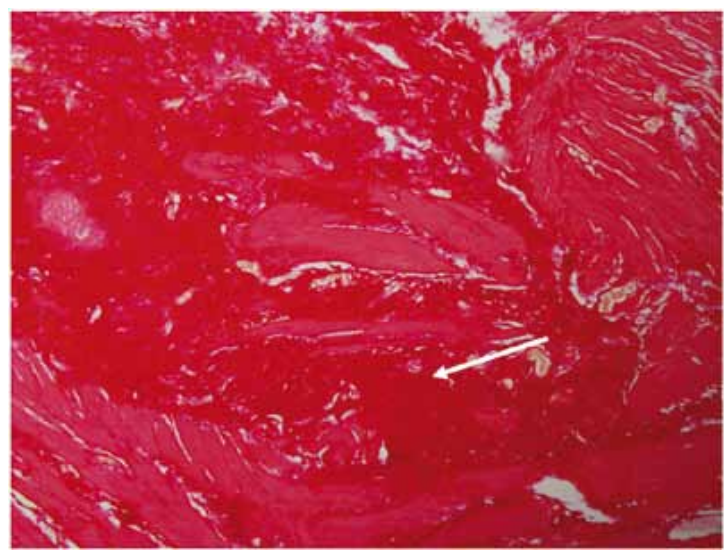

\section{B}

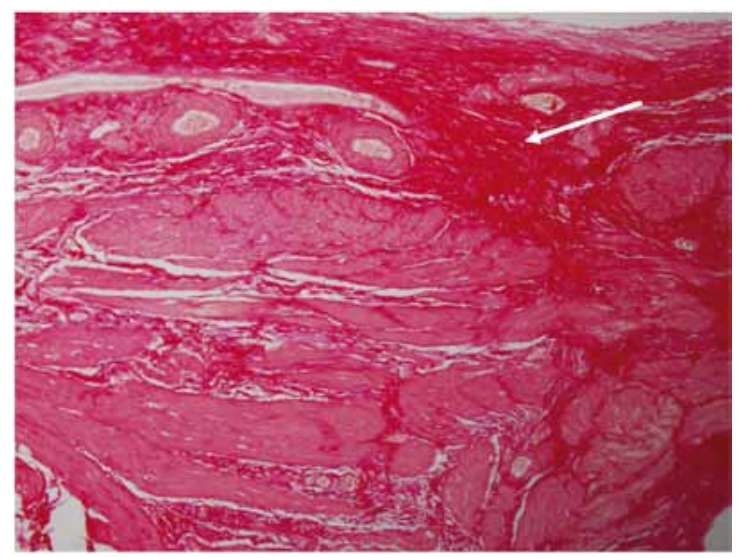

Figures 3A and 3B - Samples of groups I and III, respectively. The red color is more intense in group I. Observe the collagen fibers (arrows). Stained with Picro Sirius Red - 100X magnification.

A

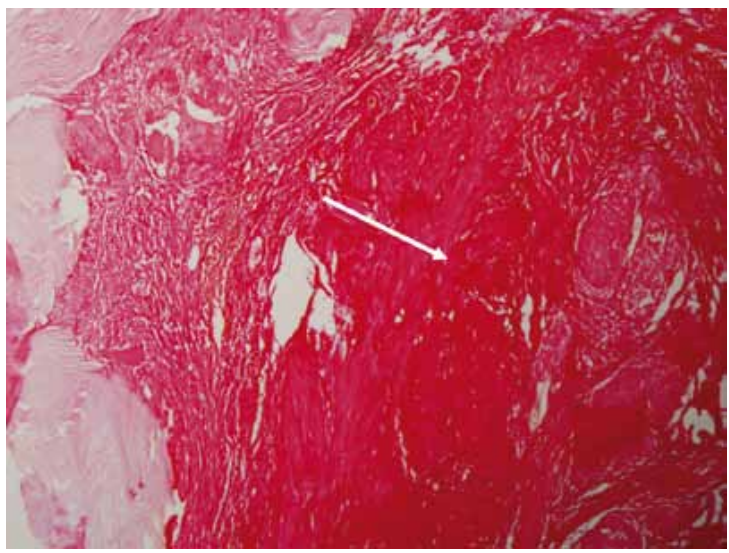

B

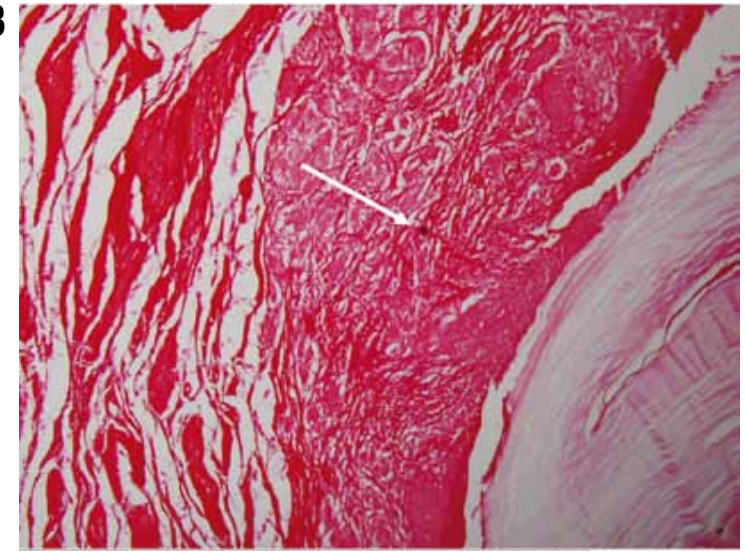


the formation of stones (10). Being absorbable materials, polyglactin 910 and BPCA can lead to the formation of stones as a transitory phenomenon facilitated by contamination of presence of infection, or influenced by some other delay of absorption, especially in less vascularized tissues. A recent study by Kosan et al. (1) using polyglactin 910 sutures, chrome catgut and polydioxanone in vesical bladder of 74 female rates analyzed their role in bladder inflammatory reaction (forein body reaction) and the formation of stones and demonstrated that, although the contact of the suture material with urine was the main factor that caused the formation of stones, the inflammatory reaction of the bladder and the physical presence of the material also played a role, and concluded that polydioxanone showed a lower degree of inflammation and didn't cause stone formation. Their design of the study was similar to ours, the animals were euthanized after 4 and 8 weeks, but they used female rats due to the facility of urethral catheterization to collect urine for the determination of $\mathrm{pH}$, leucocyte estearase and level of debris; they didn't analyze the extracellular matrix. In our study, in spite of the continued contact of the BPCA graft with the urine of rats and our surgical technique that put the surgical knot into the bladder, we observed a lower absorption of the material even after 8 weeks of exposition, and there was only one animal with bladder stone, suggesting a lithogenic potential similar to polydioxanone and much lower than polyglactin 910 .

However, maybe the lithogenic potential could be related to the capacity of the applied material induce inflammatory reaction and some studies were made using absorbable and non-absorbable sutures (17). In our experiment, we used materials that were absorbed after a significant amount of time, and there was a significant difference between the median weight of the bladders that received BPCA grafts and that were harvested after 4 weeks and after 8 weeks, when the inflammatory response was lower. When we related the bladder weight with the presence or absence of graft in all the groups, this proportion didn't show any statistical difference during the same interval of time, with a similar lowering of the bladder weight and inflammatory reaction in the groups of animals euthanized after 8 weeks, even in the presence of graft observed in $91.6 \%$ of bladders of group III and only 30\% of group IV. Hence, the biopolymer would be a material with less lithogenic potential and longer absorption in relation to polyglactin 910. A similar phenomenon was observed by Steward et al. They compared three suture materials (polydioxanone, catgut and polyglactin 910) in a cohort of 129 rats. The initial inflammatory response was higher to polydioxanone and similar to others after 6 months of follow-up. There were no significant differences among the lithogenic potential of the tested materials after 6 months and they concluded that the three materials are similar in terms of bladder surgery (2). Polydioxanone had a lower absorption than chrome catgut but similar to polyglactin 910 . So, it is possible to infer that polyglactin 910 , polydioxanone and BPCA have some similar characteristics.

Every moment a new generation of biomaterials is being developed. It is important that we have safe available methods for analysis and quantification that can be reproducible and respected by the scientific community, and the stereology seems to be an ideal method, being ease and with low cost, efficient, with no bias and reproducible (18). For quantitative analysis of inflammatory reaction due to the presence of the graft, we measured the volumetric density $(\mathrm{Vv})$ of collagen fibers in the exact place of implantation in the bladder, and compared the response with that of polyglactin 910. There was a higher median volumetric density of collagen fibers of connective tissue of bladders of group I (BPCA and euthanized after 4 weeks) in relation to the other groups, including group III (BPCA and euthanized after 8 weeks), demonstrating that there was an initial higher inflammatory reaction with BPCA that decreased to the same observed with the control group after 8 weeks. These facts are opposite to the physical presence of the graft (91.6\% of group III versus 30\% of group IV). This means that the inflammatory reaction diminished to that of the presence of BPCA after 8 weeks suggesting that the presence of bladder stones would be the main factor of inflammatory reaction and fibrosis that must be analyzed together in order to establish the lithogenic potencial. 
Biological compatible polymers as BPCA have a great capacity of use in a great number of sectors of the various and important organic systems $(15,19-23)$. The study of polymers is related to the study of nanotechnology and nanomaterials developed to be used in several chemical and cellular levels inducing cellular proliferation and modifications of the extracellular matrix allowing the recovery or formation of injured tissues. Researches involving nanoparticles for bladder substitution and the development of nanotechnology will allow the urologist a new understanding of the physiopathology and treatment of several diseases $(24,25)$. BPCA, produced with abundant and renewable raw material, belongs to a category of biomaterials that are currently being studied and its use in bladder rats will allow the development of a new material that can be used in the urological and surgical practice (26-30).

\section{CONCLUSIONS}

Sugar cane byopolimer is a material with adequate integration to rat bladders. Its absorption is slower than polyglactin 910 , and is associated with lower presence of bladder stones after grafting.

There was a higher inflammatory tissue response to the sugar cane byopolimer, directly related to the bladder weight and the presence of stones, but equal to polyglactin after 8 weeks of implantation, when tissue fibrosis was equivalent.

\section{CONFLICT OF INTEREST}

\section{None declared.}

\section{REFERENCES}

1. Kosan M, Gonulalan U, Ozturk B, Kulacoglu S, Erguder I, Akdemir 0 , et al.: Tissue reactions of suture materials (polyglactine 910, chromed catgut and polydioxanone) on rat bladder wall and their role in bladder stone formation. Urol Res. 2008; 36: 43-9.

2. Stewart DW, Buffington PJ, Wacksman J: Suture material in bladder surgery: a comparison of polydioxanone, polyglac- tin, and chromic catgut. J Urol. 1990; 143: 1261-3.

3. Fortes MA, Sadi MV: Estudo experimental comparativo com fios de sutura absorvíveis em bexiga de cães. Rev Col Bras Cir. 1996; 23: 83-8.

4. Castro CM, Aguiar JL, Melo FA, Silva WT, Marques E, Silva DB: Citotoxicidade do biopolímero de cana-de-açúcar. An Fac Med Univ Fed Pernamb. 2004; 49: 119-23.

5. Coelho MC, Carrazoni PG, Monteiro VL, Melo FA, Mota RA, Tenório Filho F: Biopolimero produzido a partir da cana-deaçúcar para cicatrização cutânea. Acta Cir Bras. 2002; 17 (Suppl 1): 11-3.

6. Chagas HM, Aguiar JLA, Andrade RT, Montoro M, Vilar FO, Lima SVC: Uso da membrana de biopolímero de cana-deaçúcar na reconstrução ureteral. International Braz J Urol. 2005; 30(Suppl 1): 43.

7. Vilar FO, Vasconcelos GB, Lima RF, Lima SV, Aguiar JL: Um novo material para tratamento da incontinência urinária: Estudo em ratas. Acta Cir Bras. 2005; 20: 13-9.

8. Lucena RG. Utilização do biopolímero de cana-de-açúcar como novo material para sling pubo vaginal: Análise estereológica [Tese Doutorado] Recife-PE. Universidade Federal de Pernambuco. 2007.

9. Melo FA: Contribuição ao estudo cinético da produção de polissacarídeos extracelulares por Zoogloea sp em melaço de cana-de-açúcar. [Dissertação Mestrado]. Recife-PE: Universidade Federal de Pernambuco. 2003.

10. VICRYL - Polyglactin 910- Suture. ETHICON Inc- A Johnson e Johnson Company. Somerville, New Jersey. Trademark. 1996.

11. Scherle W:A simple method for volumetry of organs in quantitative stereology. Mikroskopie. 1970; 26: 57-60.

12. Alves A: Análises Histopatológicas: porque demoram os resultados. ANAIS Congresso de Ciências Veterinárias, SPVC, Oeiras- Portugal. 2002; 239-47.

13. Dambros M, Rodrigues Palma PC, Mandarim-de-Lacerda CA, Miyaoka R, Rodrigues Netto N Jr.: The effect of ovariectomy and estradiol replacement on collagen and elastic fibers in the bladder of rats. Int Urogynecol J Pelvic Floor Dysfunct. 2003; 14: 108-12.

14. Delesse M: Procédé mécanique pour déterminer La composition dês roches. Ann Mines. 1848; 13: 379-85.

15. Klemm D, Schumann D, Udhardt U, Marsch S: Bacterial synthesised cellulose: artificial blood vessels for microsurgery. Prog Polym Sci. 2001; 26: 1561-603.

16. Lopes LM, Andrade CT: Polímeros de origem microbiana: polissacarídeos bacterianos. Revista de Química Industrial. 1995; 703: 19-23.

17. Morris MC, Baquero A, Redovan E, Mahoney E, Bannett AD: Urolithiasis on absorbable and non-absorbable suture materials in the rabbit bladder. J Urol. 1986; 135: 602-3.

18. Garcia Y, Breen A, Burugapalli K, Dockery P, Pandit A: Stereological methods to assess tissue response for tissueengineered scaffolds. Biomaterials. 2007; 28: 175-86. 
19. Cavalcante $A H$, Carvalho Jr. LB, Carneiro da Cunha MG. Cellulosic Exopolysaccharide produced by Zoogloea sp as a film support for trypsin immobilisation. Bio Eng J. 2006; 29: 258-61.

20. Ewald E, Malafaia A, Matias JE: Celulose liofilizada para fechamento do retroperitôneo em ratos. Arq Bra Cir Dig. 2001; 14: $129-32$.

21. Nemetz AP, Loures DR, Coelho JC: Efeito estrutural da utilização de celulose biossintética e politetrafluoretileno expandido como substitutos do peritôneo em cães. Arq Bra Cir Dig. 2001; 14: 139-42.

22. Sutherland IW: Microbial polysaccharides from Gram-negative bacteria. Int Dairy J. 2001; 11: 663-74.

23. Svensson A, Nicklasson E, Harrah T, Panilaitis B, Kaplan DL, Brittberg $\mathrm{M}$, et al.: Bacterial cellulose as a potential scaffold for tissue engineering of cartilage. Biomaterials. 2005; 26 : 419-31.

24. Pattison M, Webster TJ, Leslie J, Kaefer M, Haberstroh KM: Evaluating the in vitro and in vivo efficacy of nano-structured polymers for bladder tissue replacement applications. Macromol Biosci. 2007 10; 7: 690-700.

25. Jin S, Labhasetwar V: Nanotechnology in urology. Urol Clin North Am. 2009; 36: 179-88.
26. Vilar F0, Lima SV, Lucena RG, Aguiar JL: Utilização do Biopolímero da Cana-de-Açúcar na Túnica Albugínea: Estudo Experimental em Cães. International Brazil J Urol. 2005; 30 (Suppl 1): 126.

27. Lima SV, Aguiar JLA, Vilar FO: A New Dressig for Hypospadias Surgery. Int Braz J Urol. 2006; 32(Suppl 1): 189.

28. Rangel AE, Aguiar JL, Lima SV, Vilar F. A new biomaterial for the Treatment of Vesicoureteral Reflux: Experimental Study. Int Braz J Urol. 2006; 32 (Suppl 1): 184.

29. Chagas HM, Aguiar JL, Montoro M, Vilar F, Lima SV: Uretroplastia com Biopolímero da Cana-de-Açúcar em Cão. Int Braz J Urol. 2006; 32 (Suppl 1): 65.

30. Vilar FO, Aguiar JL, Lima SV, Lucena RG: Doença de Peyronie: Estudo de um material com perspectivas de aplicação clínica. Int Braz J Urol. 2006; 32 (Suppl 1): 167.

\section{Correspondence address:}

Dr. Arlindo Monteiro de Carvalho Junior Rua Helena Meira Lima, 542, Tambaú João Pessoa, PB, 58039-081, Brazil

Fax: + 5583 3244-5383 E-mail: amcarvalhojr@yahoo.com.br 